\title{
Amassing of Hydroxymethylfurfural, 2- Furfural and 5- Methyl furfural in orange (Citrus reticulata) juice during storage
}

\author{
Muhammad Atif RANDHAWA ${ }^{1,2}$, Muhammad Sameem JAVED ${ }^{3 *}$ (iD, Zulfiqar AHMAD ${ }^{4}$, Adnan AMJAD ${ }^{3}$, \\ Ammar Ahmad KHAN ${ }^{5}$, Faiz-ul-Hassan $\mathrm{SHAH}^{5}$, Fatima FILZA ${ }^{3}$
}

\begin{abstract}
Vitamin C is imperative component of our nutrition and used as additive in many foods owing to its high antioxidant activity. The degradation of vitamin C content in orange juice during storage was evaluated in this study. Degradation of vitamin C in orange juice during 40 days storage at $0,05,15,25$, and $40^{\circ} \mathrm{C}$ was analyzed and evaluated. Hydroxymethylfurfural (HMF) accumulation in orange juice acts as an indicator of ascorbic acid degradation. The initial vitamin $\mathrm{C}$ content in orange juice was $34.26 \mathrm{mg} / 100 \mathrm{~mL}$ that reduced when subjected to various storage conditions such as temperature and time. The loss of vitamin $\mathrm{C}$ during storage was lowest at $0{ }^{\circ} \mathrm{C}$ and the losses increased with rise in temperature. The Vitamin $\mathrm{C}$ content after 40 days in orange juice at $0{ }^{\circ} \mathrm{C}$ were $7.19 \mathrm{mg} / 100 \mathrm{~mL}$ while the Vitamin $\mathrm{C}$ content reduced to $1.89 \mathrm{mg} / 100 \mathrm{~mL}$ in orange juice that were kept at $40^{\circ} \mathrm{C}$. Hence, with increase in temperature, the Vitamin $\mathrm{C}$ was degraded and accretion of HMF, 5 methyl furfural, and 2 methyl furfural was increased. The zero-order interaction between storage time and treatment showed significant influence on HMF.
\end{abstract}

Keywords: hydroxymethylfurfural; furfural; orange juice; storage; vitamin C degradation.

Practical Application: In the current study accumulation of furfural and its compounds in orange juice was determined which are the indicator of dilapidation of Vitamin $\mathrm{C}$ in juice during storage.

\section{Introduction}

Nutritional quality of food during storage is very important (Burdurlu et al., 2006) because most of nutritional loss take place during storage. Vitamin C (ascorbic acid) is present in appreciable amount in fruit juices but unfortunately, most of content of vitamin $\mathrm{C}$ degrade during storage and the rates of loss depends upon different storage conditions (Kabasakalis et al., 2000). Vitamin C is water soluble vitamin and its deficiency leads to a disease known as scurvy which is characterized by bruising and spontaneous haemorrhages under the skin, failure of wounds to heal, soft swollen gums, bleeding of the gums, and muscle fatigue (Maxfield \& Crane, 2019).

Orange juice is an incredibly excellent source of ascorbic acid and its consumption in world is increasing at a tremendous rate. Ascorbic acid (AA) or vitamin $\mathrm{C}$ is an imperative component of human nutrition and also used as additive in many foods owing to its high antioxidant activity (Burdurlu et al., 2006; Del Caro et al., 2004). As an antioxidant, it acts as a free radical scavenger for preventing damage to the cell through by-products of chemical-cell interaction. The recommended daily allowance (RDA) for ascorbic acid is $100-120 \mathrm{mg} /$ day which can reduce the risk of numerous maladies i.e. cancer, diabetes, cardiovascular, and neurological disorders. Vitamin C content in orange juice ranged from $150-450 \mathrm{mg} / \mathrm{L}$ and one glass of orange juice $(200 \mathrm{~mL})$ can deliver about $30-80 \%$ of RDA.

Ascorbic acid is an unstable compound and it is adversely affected by time and temperature (Klimczak et al., 2007). The content of vitamin $C$ in different juices decreases during storage, depending on storage conditions such as temperature, oxygen, and amount of light exposed (Kabasakalis et al., 2000). Numerous decomposition reactive products like hydroxymethylfurfural (HMF), 2-furfural, and 5-methyl furfural are formed during the degradation of vitamin C. Both furfurals and HMF are often used as a measure of quality deterioration in citrus juices. The degradation products of ascorbic acid do not possess vitamin $\mathrm{C}$ activity. Several studies reported that furfural is one of the main degradation products of ascorbic acid or dehydro-ascorbic acid (Burdurlu et al., 2006). Storage of apple concentrates for 9 months at $25^{\circ} \mathrm{C}$ resulted in HMF formation up to $27.9 \mathrm{mg} / \mathrm{L}$ (Spanos et al., 1990).

The existing research carried out on ascorbic acid degradation and resulting compounds is scant. Also, there is insufficient data regarding the quantitative assessment of degraded compounds of vitamin $\mathrm{C}$. Therefore, keeping in view the above facts a project has been designed to evaluate the effect of storage duration

${ }^{1}$ College of Public Health, Imam Abdurrahman Bin Faisal University, Dammam, Saudi Arabia

${ }^{2}$ National Institute of Food Science \& Technology, University of Agriculture, Faisalabad, Punjab, Pakistan

${ }^{3}$ Institute of Food Science \& Nutrition, Bahauddin Zakariya University, Multan, Punjab, Pakistan

${ }^{4}$ Department of Food Science and Technology, University College of Agriculture and Environmental Sciences, The Islamia University of Bahawalpur, Bahawalpur, Punjab,

Pakistan

${ }^{5}$ University Institute of Diet and Nutritional Sciences, The University of Lahore, Punjab, Pakistan

*Corresponding author: sameemjaved@gmail.com 
as well as temperature on the degradation of ascorbic acid in orange juice. The other objective was to determine the quantity of hydroxymethylfurfural (HMF), 2-furfural, and 5-methyl furfural during storage.

\section{Materials and methods}

Fresh oranges were procured from local market. The oranges were kept at refrigeration temperature $\left(4^{\circ} \mathrm{C}\right)$ before processing into juice.

\subsection{Processing of orange juice}

Oranges were washed in tap water and cut into halves without peeling. Juice was extracted from oranges by using a rose head machine. The extraction rate of orange juice was $43 \%$. The extracted juice was heated at $80^{\circ} \mathrm{C}$ for one minute to inactivate enzymes. Following the heating process, the juice was rapidly cooled to room temperature and filtered through 8 -fold cheese cloth to eliminate granular matter.

\subsection{Storage of orange juice}

The orange juice was filled in pre-sterilized glass jars, sealed and kept in darkness at $0,5,15,25$, and $40^{\circ} \mathrm{C}$ for storage period of 40 days. The juice samples were analyzed for the presence of degraded products of ascorbic acid like HMF, 2-furfural, and 5-methyl furfural at an interval of 10 days for duration of 40 days.

\subsection{Determination of ascorbic acid}

Ascorbic acid was determined by using high performance liquid chromatography (HPLC) (Akalin et al., 2002) as given below. $7 \mathrm{~mL}$ of juice was added to $40 \mathrm{~mL}$ of buffer-acetonitrile mobile phase $\left(0.5 \%(\mathrm{wt} / \mathrm{vol})\left(\mathrm{NH}_{4}\right)_{2} \mathrm{HPO}_{4}(0.038 \mathrm{M}) 0.4 \%\right.$ (vol/vol) acetonitrile $(0.049 \mathrm{M})$, at $\mathrm{pH} 2.24$ with $\left.\mathrm{H}_{3} \mathrm{PO}_{4}\right)$, extracted for
1 hour in orbital shaker (model 75, Burrell Scientific, Pottsburgh, PA), and centrifuged at $6000 \mathrm{x}$ g for 5 minutes. The supernatant was collected and filtered once through Whatman No. 1 filter paper and twice through a $0.45-\mu \mathrm{m}$ membrane filter (Satorious SM 11606, Goettingen, Germany) and then used directly for HPLC analysis. Triplicate analyses were performed on all samples. Analysis of ascorbic acid was made by HPLC with UV detector (Perkin Elmer-series 200) at $214 \mathrm{~nm}$ using RP-18 column $(25 \mathrm{~cm} \times 4.6 \mathrm{~mm}$ id). Quantification was based on the external standard method for accuracy while the Standard chromatogram is depicted in Figure 1.

\subsection{Determination of furfuraldeydes}

HMF, 2-Furfural, and 5-Methyl furfural were also determined using high performance liquid chromatography (HPLC) (Gökmen \& Acar, 1999) as detailed below.

A $5 \mathrm{~mL}$ volume of orange juice was extracted twice, using a vortex mixer, with $10 \mathrm{~mL}$ of ethyl acetate by shaking vigorously for $1 \mathrm{~min}$. The organic phases were combined and extracted with $2 \mathrm{~mL}$ of $1.5 \%$ sodium carbonate solution along with shaking for $1 \mathrm{~min}$. The phases were allowed to separate and the aqueous phase was immediately extracted with $5 \mathrm{~mL}$ of ethyl acetate by shaking for $1 \mathrm{~min}$. The combined organic phases to a total volume of $25 \mathrm{~mL}$ were dried over $2.5 \mathrm{~g}$ of anhydrous sodium sulfate. Subsequently, the dried extract was filtered through Whatman No. 1 filter paper to remove the remaining particles of anhydrous sodium sulfate. A $2 \mathrm{~mL}$ excess of ethyl acetate was added to wash the filter cake layer and the filtrate obtained was combined with the filtered extract. Then, the extract was evaporated just to dryness in a water bath at $40^{\circ} \mathrm{C}$ under a gentle stream of nitrogen. The residue was immediately re-dissolved in $500 \mu \mathrm{L}$ of HPLC water ( $\mathrm{pH} 4.0$ ) and $20 \mu \mathrm{L}$ of this solution was

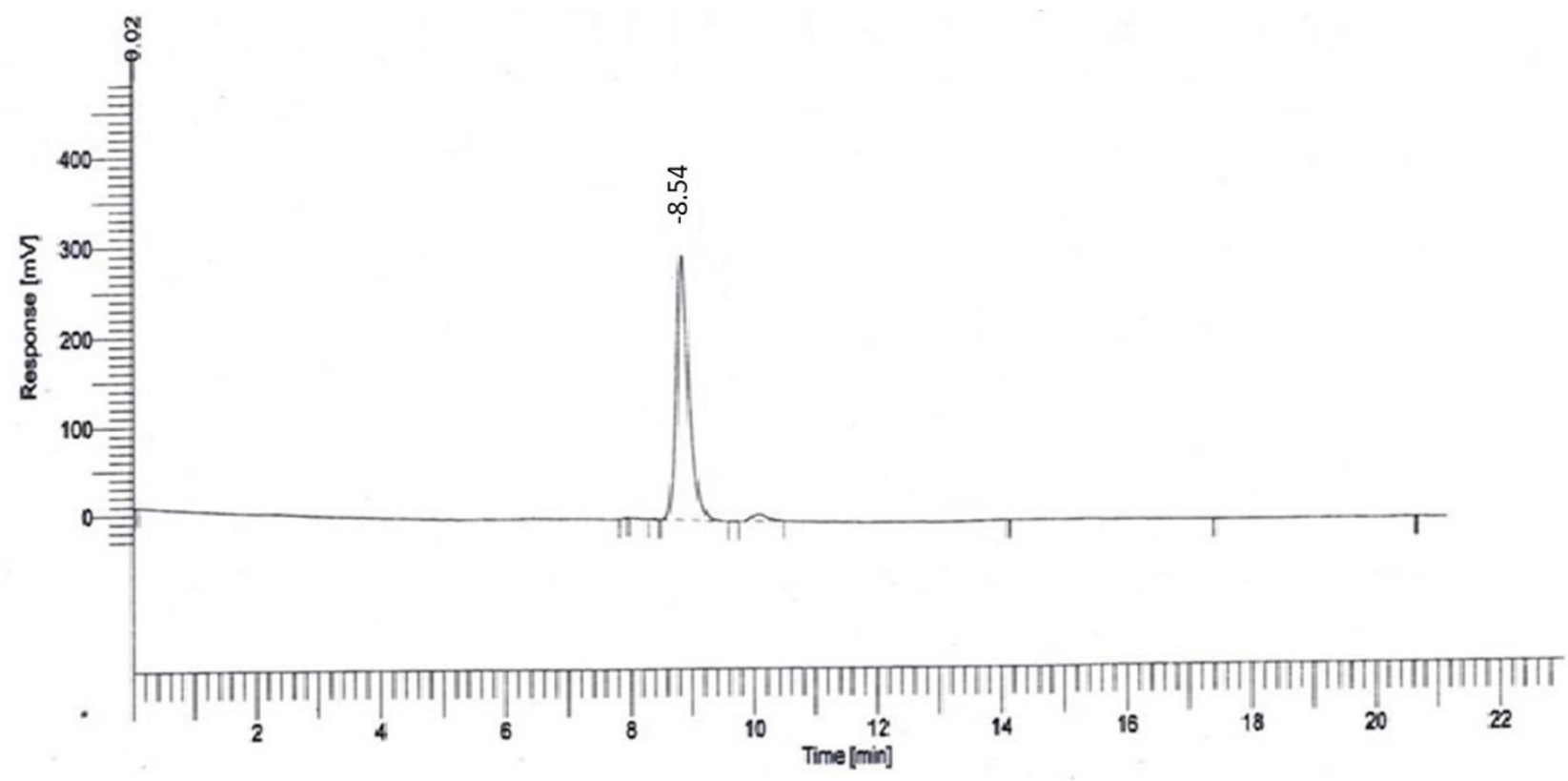

Figure 1. Standard Chromatogram of Ascorbic Acid. 
injected into the column. The final solutions were kept frozen $\left(-18^{\circ} \mathrm{C}\right)$ until the chromatographic measurements.

Stock solutions of hydroxymethylfurfural, 5-methyl furfural, and 2-furfural were prepared by dissolving $1 \mathrm{~g}$ of each standard in $100 \mathrm{~mL}$ of ethyl acetate, then diluting these solutions 1:50 (v/v) by ethyl acetate to obtain a final concentration of $0.2 \mathrm{mg} / \mathrm{mL}$ for each compound. A $100 \mathrm{~mL}$ volume (each standard) of these stock solutions was transferred into $10 \mathrm{~mL}$ volumetric flasks and evaporated just to dryness under a gentle stream of nitrogen at room temperature. The residues were immediately dissolved in $10 \mathrm{~mL}$ of water ( $\mathrm{pH} 4.0$ ) acidified with acetic acid. Working standard solutions were prepared by appropriate dilution of these solutions with water $(\mathrm{pH} 4.0)$.

Quantification was done based on external standard method while the Standard chromatogram is depicted in Figure 2.

\subsection{Statistical analysis}

The data was imperiled to statistical analysis to determine the level of significance using 2-factor factorial CRD following the principles outlined by Steel et al. (1997).

\section{Results and discussion}

\subsection{Loss of vitamin C during storage}

Losses of vitamin C have been depicted in Table 1. Results showed that initial content of ascorbic acid in orange juice was $34.27 \mathrm{mg} / 100 \mathrm{~mL}$. After 40 days of storage at $0,5,15,25$, and $40{ }^{\circ} \mathrm{C}$ the ascorbic acid content of samples decreased to $7.19,3.04,2.33,2.22$, and $1.89 \mathrm{mg} / 100 \mathrm{~mL}$ respectively.

It was observed during the experiment that destruction of vitamin $\mathrm{C}$ was much faster at the start of storage and after 10 days of storage at $0,5,15,25$, and $40^{\circ} \mathrm{C}$ the ascorbic acid content of samples decreased drastically by $65.94,86.81,83.39,90.11$, and $91.10 \%$, respectively but afterwards the decrease in vitamin $\mathrm{C}$ content was rather slow.

At the end of storage, the loss of vitamin $\mathrm{C}$ content was $79.01,91.13,93.20,93.52$, and $94.48 \%$ respectively at different storage temperatures mentioned above as compared to the start of the study. Ascorbic acid loss was more pronounced at $40^{\circ} \mathrm{C}$ and it showed maximum decrease in ascorbic acid content throughout the storage period. The study showed that the decrease in the ascorbic acid content during storage was directly proportional to

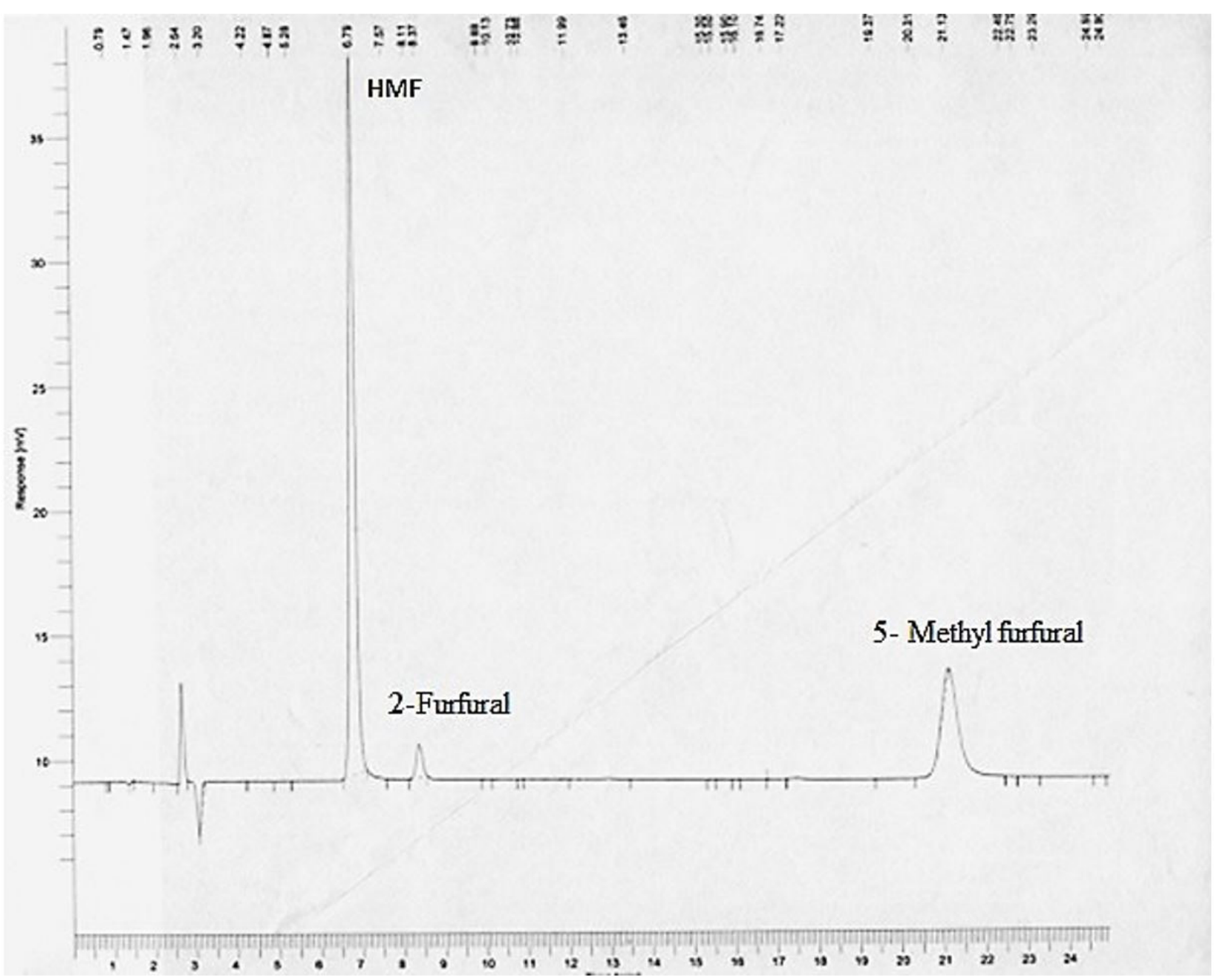

Figure 2. Standard Chromatogram of HMF, 2-Furfural, 5-Methyl furfural. 
the storage temperature, as the storage temperature increase the degradation of vitamin $\mathrm{C}$ become higher and vice versa. The effect of different storage temperatures on orange juice concentrates was also studied by Burdurlu et al. (2006). They reported that the ascorbic acid content decrease with increasing storage temperature of citrus juice concentrates. They observed that the loss of ascorbic acid was much more in citrus juice concentrates at $45^{\circ} \mathrm{C}$ rather than at $28^{\circ} \mathrm{C}$.

Previous literature also exhibited that the ascorbic acid content in different juices decreased during storage, depending on storage conditions, such as temperature, oxygen, and light access (Kabasakalis et al., 2000). Recently, first-order rate constants for nonenzymic browning and ascorbic acid loss of membrane-clarified clear juice, during conventional evaporative processes at $70.3-97.6{ }^{\circ} \mathrm{C}$, have been presented (Johnson et al., 1995).

\subsection{Evaluation of furfuraldehydes}

The sensitivity of the method for the determination of HMF, 2-Furfural, and 5- Methyl furfural concentrations was checked before using the method. Detection sensitivity of furfuraldehydes was found to be more than any spectrophotometric method. On the basis of 3:1 signal/noise ratio the sensitivity was determined to be $<0.015 \mathrm{mg} / \mathrm{L}$ for HMF and $<0.035 \mathrm{mg} / \mathrm{L}$ for both 2-Furfural and 5- Methyl furfural.
HMF concentrations of orange juice are given in the Table 2. After 40 days storage, HMF content of orange juice at $25^{\circ} \mathrm{C}\left(\mathrm{T}_{4}\right)$ ranged from $0.35 \mu \mathrm{g} / 100 \mathrm{~mL}$ to $239.01 \mu \mathrm{g} / 100 \mathrm{~mL}$. The variation of $\mathrm{HMF}$ at $40^{\circ} \mathrm{C}\left(\mathrm{T}_{5}\right)$ was between $0.35 \mu \mathrm{g} / 100 \mathrm{~mL}$ to $821.88 \mu \mathrm{g} / 100 \mathrm{~mL}$. The increase of $\mathrm{HMF}$ at $40{ }^{\circ} \mathrm{C}$ was approximately 3.4 times higher than that of at $25^{\circ} \mathrm{C}$. When HMF content in orange juice plotted versus storage time, the best fit model for HMF accumulation was zero-order reaction.

Similarly the concentrations of 2-Furfural was found to be increased during storage and this accumulation was more pronounced due to temperature abuse. The increase in 2-Furfural content of orange juice at $40^{\circ} \mathrm{C}$ was approximately 7.4 times higher than that of at $25^{\circ} \mathrm{C}$. In contrast to the above two furfuraldehydes, 5- Methyl furfural which was first time studied with both HMF and 2- Furfural showed a different nature. It showed the maximum accumulation at $25^{\circ} \mathrm{C}$ where its concentration was $2.63 \mu \mathrm{g} / 100 \mathrm{~mL}$ while at $40^{\circ} \mathrm{C}$, a decrease in its concentration was observed.

A significant correlation ranged from 0.675 to 0.880 between vitamin $\mathrm{C}$ loss and HMF accumulation $(\mathrm{p}<0.05)$ was obtained during the storage of orange juice. Accumulation of HMF in orange juice during storage is mainly attributed by the degradation of ascorbic acid. The same phenomenon was also observed by other scientists in citrus juice concentrates (Burdurlu et al.,

Table 1. Effect of storage temperature and duration on the Ascorbic acid $(\mathrm{mg} / 100 \mathrm{~mL})$ in orange juice.

\begin{tabular}{|c|c|c|c|c|c|}
\hline \multirow{2}{*}{ Temperature $\left({ }^{\circ} \mathrm{C}\right)$} & \multicolumn{5}{|c|}{ Storage (Days) } \\
\hline & 0 & 10 & 20 & 30 & 40 \\
\hline 0 & $34.27 \pm 0.21 \mathrm{~A}$ & $11.67 \pm 1.74 \mathrm{~B}$ & $11.28 \pm 2.34 \mathrm{~B}$ & $10.94 \pm 1.79 \mathrm{BC}$ & $7.19 \pm 1.51 \mathrm{C}$ \\
\hline 5 & $34.27 \pm 0.21 \mathrm{~A}$ & $4.52 \pm 0.32 \mathrm{E}$ & $4.14 \pm 0.87 \mathrm{E}$ & $3.39 \pm 1.33 \mathrm{EF}$ & $3.04 \pm 2.24 \mathrm{~F}$ \\
\hline 15 & $34.27 \pm 0.21 \mathrm{~A}$ & $5.69 \pm 1.45 \mathrm{D}$ & $3.39 \pm 0.54 \mathrm{EF}$ & $3.01 \pm 0.56 \mathrm{~F}$ & $2.33 \pm 1.39 \mathrm{G}$ \\
\hline 25 & $34.27 \pm 0.21 \mathrm{~A}$ & $3.39 \pm 0.66 \mathrm{EF}$ & $3.18 \pm 0.8 \mathrm{EF}$ & $2.26 \pm 0.78 \mathrm{G}$ & $2.22 \pm 1.67 \mathrm{G}$ \\
\hline 40 & $34.27 \pm 0.21 \mathrm{~A}$ & $3.05 \pm 0.57 \mathrm{~F}$ & $2.65 \pm 0.7 \mathrm{G}$ & $2.26 \pm 0.45 \mathrm{G}$ & $1.89 \pm 1.49 \mathrm{H}$ \\
\hline
\end{tabular}

Letters present in the table showed that data is significantly changing, and values are statistically significant with changing conditions.

Table 2. Effect of storage temperature and duration on the Furfuraldehydes formation $(\mu \mathrm{g} / 100 \mathrm{~mL})$ in orange juice.

\begin{tabular}{|c|c|c|c|c|c|c|}
\hline \multirow{2}{*}{ Furfuraldehydes } & \multirow{2}{*}{$\begin{array}{c}\text { Temperature } \\
\left({ }^{\circ} \mathrm{C}\right)\end{array}$} & \multicolumn{5}{|c|}{ Storage (Days) } \\
\hline & & 0 & 10 & 20 & 30 & 40 \\
\hline \multirow[t]{5}{*}{ HMF } & 0 & $0.35 \pm 0.07 \mathrm{I}$ & $15.57 \pm 0.31 \mathrm{H}$ & $16.18 \pm 0.32 \mathrm{H}$ & $22.38 \pm 0.44 \mathrm{GH}$ & $36.53 \pm 0.71 G$ \\
\hline & 5 & $0.35 \pm 0.07 \mathrm{I}$ & $20.63 \pm 0.40 \mathrm{GH}$ & $25.13 \pm 0.49 \mathrm{GH}$ & $32.28 \pm 0.63 G$ & $35.4 \pm 0.69 G$ \\
\hline & 15 & $0.35 \pm 0.07 \mathrm{I}$ & $37.82 \pm 0.02 \mathrm{G}$ & $20.99 \pm 0.41 \mathrm{GH}$ & $21.46 \pm 0.42 \mathrm{GH}$ & $25.26 \pm 0.49 \mathrm{GH}$ \\
\hline & 25 & $0.35 \pm 0.07 \mathrm{I}$ & $93.58 \pm 1.83 \mathrm{~F}$ & $103.47 \pm 2.03 \mathrm{EF}$ & $141.74 \pm 2.78 \mathrm{E}$ & $239.01 \pm 4.68 \mathrm{D}$ \\
\hline & 40 & $0.35 \pm 0.07 \mathrm{I}$ & $362.6 \pm 7.11 \mathrm{C}$ & $418.94 \pm 8.21 \mathrm{BC}$ & $475.21 \pm 9.32 \mathrm{~B}$ & $821.88 \pm 16.11 \mathrm{~A}$ \\
\hline \multirow[t]{5}{*}{ 2- Furfural } & 0 & $0.85 \pm 0.018 \mathrm{~J}$ & $1.06 \pm 0.02 \mathrm{IJ}$ & $1.08 \pm 0.02 \mathrm{IJ}$ & $1.22 \pm 0.02 \mathrm{HI}$ & $1.4 \pm 0.02 \mathrm{H}$ \\
\hline & 5 & $0.85 \pm 0.018 \mathrm{~J}$ & $1.02 \pm 0.02 \mathrm{IJ}$ & $1.12 \pm 0.02 \mathrm{I}$ & $1.19 \pm 0.03 \mathrm{HI}$ & $2.28 \pm 0.04 \mathrm{G}$ \\
\hline & 15 & $0.85 \pm 0.018 \mathrm{~J}$ & $2.26 \pm 0.05 G$ & $2.8 \pm 0.06 \mathrm{FG}$ & $4.22 \pm 0.08 \mathrm{EF}$ & $15.93 \pm 0.32 \mathrm{D}$ \\
\hline & 25 & $0.85 \pm 0.018 \mathrm{~J}$ & $3 \pm 0.06 \mathrm{~F}$ & $4.48 \pm 0.09 \mathrm{EF}$ & $6.87 \pm 0.14 \mathrm{E}$ & $35.28 \pm 0.730 \mathrm{C}$ \\
\hline & 40 & $0.85 \pm 0.018 \mathrm{~J}$ & $2.78 \pm 0.06 \mathrm{FG}$ & $19.63 \pm 0.41 \mathrm{D}$ & $143.13 \pm 2.96 \mathrm{~B}$ & $260.23 \pm 5.38 \mathrm{~A}$ \\
\hline \multirow[t]{5}{*}{ 5- Methyl furfural } & 0 & $\mathrm{ND}$ & ND & $0.88 \pm 0.03 \mathrm{EF}$ & $1.28 \pm 0.04 \mathrm{DE}$ & $1.94 \pm 0.06 \mathrm{~B}$ \\
\hline & 5 & $\mathrm{ND}$ & $0.87 \pm 0.03 \mathrm{EF}$ & $1.02 \pm 0.04 \mathrm{E}$ & $1.22 \pm 0.04 \mathrm{DE}$ & $1.49 \pm 0.05 \mathrm{CD}$ \\
\hline & 15 & $\mathrm{ND}$ & $1.33 \pm 0.05 \mathrm{D}$ & $1.47 \pm 0.05 \mathrm{CD}$ & $1.65 \pm 0.06 \mathrm{C}$ & $1.94 \pm 0.06 \mathrm{~B}$ \\
\hline & 25 & $\mathrm{ND}$ & $1.46 \pm 0.05 \mathrm{CD}$ & $1.8 \pm 0.06 \mathrm{BC}$ & $1.8 \pm 0.06 \mathrm{BC}$ & $2.63 \pm 0.09 \mathrm{~A}$ \\
\hline & 40 & $\mathrm{ND}$ & ND & ND & $\mathrm{ND}$ & $0.94 \pm 0.03$ \\
\hline
\end{tabular}

Letters present in the table showed that data is significantly changing, and values are statistically significant with changing conditions. ND = Not Detected. 
2006). However, sugar degradation may also be contributed to HMF accumulation in orange juice to some extent.

Tatum et al. (1969) also conducted a work upon the degradation products from ascorbic acid and identified the following furans: furfural, 2-acetyIfuran, 2, 2-difurylmethane, furfuryl alcohol, 2-hydroxyacetyl furan, 2,5-dihydrofuroic acid, deoxyfuroin, 2-furoic acid, furoin, and furil. They confirmed the identity of most of the compounds by comparing their infrared and ultraviolet spectra, mass spectral cracking patterens and retention times on Carbowax 20M with those of commercially available samples. Nagy \& Randall (1973) measured the furfural during the 16 weeks of storage in canned orange juice at $5,10,16,21$, and $30^{\circ} \mathrm{C}$. Their studies revealed that at every $5^{\circ} \mathrm{C}$, rise in temperature, there was an approximate double increase in the amount of furfural in canned orange juice. Organoleptic evaluation showed that at the level of $55 \mu \mathrm{g} / \mathrm{L}$ furfural content, the taste of juice was unacceptable to taste panel.

\section{Conclusion}

It was concluded from above mentioned results that ascorbic acid in orange juice decreased with increasing temperature. The loss of ascorbic acid in orange juice at all storage temperatures was described as a zero-order reaction. On the other hand HMF, 2-Furfural, and 5- Methyl furfural accumulation of orange juice increased depending on storage temperature. It was also observed that the increase of HMF, 2- Furfural and 5- Methyl furfural accumulation in orange juice at $40{ }^{\circ} \mathrm{C}$ was higher than that of at $25^{\circ} \mathrm{C}$. An inverse relationship was found between ascorbic acid and furfuraldehyde accumulation. HMF, 2-Furfural and 5- Methyl furfural concentrations of orange juice were found to be increased with an increase in ascorbic acid degradation. Hence, ascorbic acid content was reduced so as vitamin C activity.

\section{References}

Akalin, A. S., Gönç, S., \& Akbaş, Y. (2002). Variation in organic acids content during ripening of pickled white cheese. Journal of Dairy Science, 85(7), 1670-1676. http://dx.doi.org/10.3168/jds.S00220302(02)74239-2. PMid:12201516.
Burdurlu, H. S., Koca, N., \& Karadeniz, F. (2006). Degradation of vitamin $\mathrm{C}$ in citrus juice concentrates during storage. Journal of Food Engineering, 74(2), 211-216. http://dx.doi.org/10.1016/j. jfoodeng.2005.03.026.

Del Caro, A., Piga, A., Vacca, V., \& Agabbio, M. (2004). Changes of flavonoids, vitamin $\mathrm{C}$ and antioxidant capacity in minimally processed citrus segments and juices during storage. Food Chemistry, 84(1), 99-105. http://dx.doi.org/10.1016/S0308-8146(03)00180-8.

Gökmen, V., \& Acar, J. (1999). Simultaneous determination of 5-hydroxymethylfurfural and patulin in apple juice by reversed-phase liquid chromatography. Journal of Chromatography A, 847(1-2), 69-74. http://dx.doi.org/10.1016/S0021-9673(99)00133-8. PMid:10431352.

Johnson, J. R., Braddock, R. J., \& Chen, C. S. (1995). Kinetics of ascorbic acid loss and nonenzymatic browning in orange juice serum: experimental rate constants. Journal of Food Science, 60(3), 502-505. http://dx.doi.org/10.1111/j.1365-2621.1995.tb09812.x.

Kabasakalis, V., Siopidou, D., \& Moshatou, E. (2000). Ascorbic acid content of commercial fruit juices and its rate of loss upon storage. Food Chemistry, 70(3), 325-328. http://dx.doi.org/10.1016/S03088146(00)00093-5.

Klimczak, I., Małecka, M., Szlachta, M., \& Gliszczyńska-Świgło, A. (2007). Effect of storage on the content of polyphenols, vitamin C, and antioxidant activity of orange juices. Journal of Food Composition, 20(3-4), 313-322. http://dx.doi.org/10.1016/j.jfca.2006.02.012.

Maxfield, L., \& Crane, J. S. (2019). Vitamin C deficiency (scurvy). Treasure Island: StatPearls Publishing. Retrieved from https://www.ncbi.nlm. nih.gov/books/NBK493187/

Nagy, S., \& Randall, V. (1973). Use of furfural content as an index of storage temperature abuse in commercially processed orange juice. Journal of Agricultural and Food Chemistry, 21(2), 272-275. http:// dx.doi.org/10.1021/jf60186a025.

Spanos, G. A., Wrolstad, R. E., \& Heatherbell, D. A. (1990). Influence of processing and storage on the phenolic composition of apple juice. Journal of Agricultural and Food Chemistry, 38(7), 1572-1579. http://dx.doi.org/10.1021/jf00097a031.

Steel, R. G. D., Torrie, J. H., \& Dickey, D. A. (1997). Principles and procedures of statistics. In R. G. D. Steel, J. H. Torrie, \& D. A. Dickey (Eds.), A biometrical approach (3rd ed., pp. 352-399). New York: McGraw-Hill.

Tatum, J. H., Shaw, P. E., \& Berry, R. E. (1969). Degradation products from ascorbic acid. Journal of Agricultural and Food Chemistry, 17(1), 38-40. http://dx.doi.org/10.1021/jf60161a008. 